\title{
Timothy Snyder, Skrwawione ziemie. Europa między Hitlerem a Stalinem, tłum. Bartłomiej Pietrzyk, Warszawa: Świat Książki, 2011, 544 s.
}

Ciekawa, acz kontrowersyjna (co w wypadku książek historycznych jest określeniem pozytywnym) monografia Timothy'ego Snydera Skwawione ziemie musiała wzbudzić spore emocje wśród historyków. Jej wydanie wiąże się bowiem z wyraźnym nasileniem „ofensywnej polityki historycznej” w kilku państwach Europy Wschodniej - na Litwie, Łotwie i Estonii oraz w Rumunii i w mniejszym stopniu na Ukrainie.

Co do książki Timothy’ego Snydera mam ambiwalentne uczucia. Z pewnością publikacja ta cieszy polskie, i nie tylko polskie, serca. Kontekstem dla tej dosyć powszechnej w Polsce radości jest zaskakująca rywalizacja między europejskimi narodami, mianowicie rywalizacja o to, który z narodów najwięcej wycierpiał w swoich dziejach, szczególnie zaś w latach drugiej wojny światowej. W rankingu narodowych cierpień ważny jest także dystans, jaki poszczególnych rywali w tym wyścigu dzieli, chronologia, dynamika i wymiar prześladowań, jakie dotknęły poszczególne narody. $\mathrm{W}$ walce o wysokie miejsce $\mathrm{w}$ rankingu notujemy zaskakujące sojusze różnych państw, czyli de facto tamtejszych opiniotwórczych elit, realizujących nierzadko czysto polityczne zamówienie, by wesprzeć któreś z walczących o władzę ugrupowań.

Dopóki istniał Związek Sowiecki, w Europie Środkowej i Wschodniej głównym prześladowcą europejskich narodów były - co do pewnego stopnia zrozumiałe, gdyż nikt nie chciał z mocarstwem zadzierać - Niemcy nazistowskie. Od czasów Stalina główną ofiarą był wspomniany Związek Sowiecki, bez różnicowania, które z jego narodów cierpiały najbardziej. Co najwyżej narodowe diaspory upominały się o odpowiednie wyeksponowanie swojej pozycji. Nie było też mowy, by mieszkańców Niemiec nazistowskich potraktować w pewnych kontekstach także jako ofiary.

Na Zachodzie opinie układały się nieco inaczej, ale do lat sześćdziesiątych, a nawet siedemdziesiątych zgodnie przyznawano, że największe ofiary wojny poniósł Związek Sowiecki. Niemieccy historycy chętnie dodawali, że wśród pokrzywdzonych narodów jako pierwszych należy wymieniać Białorusinów i wschodnioeuropejskich Żydów. Wiele w tej optyce zmienił proces Adolfa Eichmanna i upowszechniająca się wiedza o rozmiarze Holokaustu. W ciągu dekady naród żydowski wysunął się na czoło rywalizacji pamięci o zamordowanych, zostawiając daleko $\mathrm{w}$ tyle wszystkie inne narody europejskie. Od początku lat osiemdziesiątych studia nad różnymi formami antysemityzmu i szczególnie nad samym procesem Zagłady nabrały ogromnego przyspieszenia i zaowocowały tysiącami monografii. Zapanował konsensus w sprawie uznania zagłady Żydów za największą zbrodnię w dziejach ludzkości. Nic nie zmieniły w tej kwestii próby odwołania się do szerszej kategorii 
genocide, mimo że do ludobójstwa dochodziło także w latach siedemdziesiątych i osiemdziesiątcyh (Kambodża, Afryka).

Mimo wojennych doświadczeń narody Europy, zwłaszcza Europy Wschodniej i Środkowej, pozostały w sporej części antysemickie i ksenofobiczne, kultywując swoją etniczną homogeniczność. Przekonanych antysemitów ciągłe przypominanie żydowskich ofiar drugiej wojny światowej coraz silniej utwierdzało w ich paranoicznych obsesjach o żydowskim światowym spisku. W tej konstrukcji umysłowej Żydzi, nie mogąc swojego wybraństwa i wyjątkowości oprzeć na uznaniu ich zasług dla rozwoju nowoczesności, zdecydowali się na wykorzystanie mitu „niewinnej ofiary”, którą cały świat - oczywiście, różne narody w różnym stopniu - musi prosić o wybaczenie.

Związek Sowiecki podobnie jak carska Rosja nigdy nie cieszył się w opinii wschodnich Europejczyków dobrą opinią. Wyjątkiem były do pewnego stopnia Czechy i Bułgaria, wcześniej wsparte przez Rosję w swojej walce narodowowyzwoleńczej. Imperium sowieckie nie było pokojowo nastawione wobec emancypujących się państw narodowych powstałych w wyniku rewolucji październikowej na gruzach carskiej Rosji. Po części było to zrozumiałe, imperia mają w ogóle tendencję do ekspansji. W czasach rewolucyjnych zewnętrzna ekspansja służyła też odwróceniu uwagi własnego społeczeństwa od kosztów przemian wewnętrznych. Imperia w okresach transformacji muszą opierać się na jakiejś ideologii, nadającej sens przemianom. Czy wybór akurat ideologii marksistowskiej był przypadkowy, czy też nieunikniony, pozostaje kwestią otwartą i setki sowietologów w tej sprawie od dziesięcioleci się spierają. Pozostaje faktem, że idee mówiące o równości wszystkich ludzi i ich przyrodzonym braterstwie zostały wykorzystane do zaprowadzenia skrajnej nierówności, podzieliły społeczeństwo na posłusznych wykonawców woli rządzących elit oraz uwięzionych w łagrach niewolników. Realizacja tego nowego podziału pociągnęła za sobą miliony śmiertelnych ofiar. Ofiarami padali wszyscy niezadowoleni z wprowadzanych nowych zasad społecznych - likwidowani według zmieniających się kryteriów. Raz były to sympatie polityczne, innym razem przywiązanie do religii czy własności prywatnej. Niemniej jednak prześladowani zawsze należeli do jakiegoś narodu, łatwo było więc ich zaliczyć do „naszych” ofiar - szczególnie z punktu widzenia diaspory tego samego narodu, znajdującej się poza granicami Związku Sowieckiego.

Po represjach sowieckich przyszły represje niemieckie, gdy Niemcy nazistowskie zaatakowały Polskę we wrześniu 1939 r., a dwa lata później Związek Sowiecki. Narody dotknięte wojnami (polsko-sowiecka z 1920 r.) bądź sowieckimi represjami ponownie stały się przedmiotem terroru i represji. Do milionów ofiar doszły kolejne miliony. Dla ofiar drugorzędne znaczenie miał powód prześladowań, nawet jeśli był to odwet za opór wojskowy wobec okupanta. Liczyła się skala terroru i jego efektywność. Wszystko działo się na tym samym terytorium - w Europie Środkowej i Wschodniej.

Timothy'ego Snydera zafascynował właśnie ten fakt - zamordowanie przez reżimy Stalina i Hitlera w środku Europy (od Odry po Dniepr) w ciągu dwunastu 
lat 14 mln osób. Nie byli to żołnierze walczących armii, lecz cywile, w większości kobiety i dzieci. Żydzi stanowili wśród ofiar znacznie mniej niż połowę - 5,5 mln. Ten masowy mord miał swoją chronologię i dynamikę - najpierw mordował niewinne ofiary Stalin, później Stalin wspólnie z Hitlerem najpierw w okresie bliskiej współpracy w latach 1939-1941, a następnie walcząc ze sobą, przy czym najwięcej ofiar przyniósły lata 1941-1945, kiedy byli sprzymierzeńcy zwrócili się przeciw sobie. Także większość ofiar nie zginęła w komorach gazowych, lecz w wyniku masowych, do pewnego stopnia tradycyjnych egzekucji. Jako pierwszych zaczęto mordować masowo nie Żydów, ale sowieckich jeńców wojennych, których ponad 2 mln zagłodzono.

Te proste i oczywiste fakty nie tłumaczą, dlaczego wiele osób nadal nie może zgodzić się, że obie formy ludobójstwa można rozpatrywać łącznie, gdyż inaczej nie zrozumiemy ich przyczyn. Snyder pisze, że historie narodowe opierają się ciągle nazistowskiej i sowieckiej konceptualizacji popełnionych zbrodni, utrwalają je, „dzieląc przeszłość Europy na części odpowiadające poszczególnym narodom i dbając, by się one nie stykały” (s. 19). Jego zaś zdaniem wyjaśnienie tego, „co spotkało jedną grupę, bywa często zrozumiałe tylko w świetle tego, co stało się z inną" (s. 20).

Punkt wyjścia Snydera wydaje się ze wszech miar słuszny, nie on pierwszy wpadł na ten pomysł, że odwołam się do nazwisk tak znanych biografów Stalina i Hitlera, jak Ian Kershaw i Alan Bullock, problemem jest jednak, jak tę wspólną europejską historię opowiedzieć. Chronologii nie da się pominąć, do 1933 r. opowiadać więc należy jedynie o zbrodniach Stalina. Następny okres - lata 1933-1939 - daje już pewne możliwości porównawcze, choć oczywiste jest, że bilans zbrodni Niemiec nazistowskich w tym czasie jest ułamkiem „dokonań” stalinowskiej Rosji. W ciągu kolejnych dwóch lat ofiar terroru komunistycznego było nadal więcej niż nazistowskiego, różnica była jednak już nie tak wielka. Sytuacja odwróciła się po 22 czerwca 1941 r. i napadzie Niemiec na Związek Sowiecki. Najpierw agresor, a po dwóch latach strona napadnięta w miejsce dotychczas dosyć tradycyjnych działań frontowych i okupacyjnych przeszli do wojny na wyniszczenie, skierowanej w większym stopniu wobec cywilnego zaplecza niż wrogich armii.

Problemem jest więc nie kiedy, lecz kogo mordowano i z jakich powodów. W tym miejscu zaczyna się pionierska rola Snydera w licznym i doświadczonym gronie zachodnioeuropejskich historyków nowoczesności. Zazwyczaj ułatwiali oni sobie pracę, decydując się na studia sowietologiczne bądź brali na warsztat Niemcy nazistowskie. Oprócz prywatnych zainteresowań o wyborze tematyki decydowały możliwości warsztatowe, w pierwszym wypadku znajomość języków słowiańskich i odwaga zmierzenia się ze szczelnie zamkniętymi do pewnego momentu archiwami na wschód od Odry. W drugim imperatyw historii porównawczej natrafiał na niezmierne bogactwo narodowej historiografii niemieckiej i po jej wykorzystaniu znacznie słabł. Snyder nauczył się wspomnianych języków, odwiedził kilka ważnych archiwów, ale przede wszystkim zgromadził solidną bibliotekę z nowszymi opracowaniami narodowych historiografii dotyczącymi interesujących 
go zagadnień. Solidną nie znaczy, niestety, pełną, historycy także w tym regionie pracują intensywnie, zabrakło więc w jego bibliotece wielu ostatnio opublikowanych pozycji, szczególnie dotyczących zagadnień regionalnych. To, co zgromadził, wystarczyło i tak z nawiązką, by zaplanowaną do opowiedzenia historię interesująco poprowadzić. Nie jest moim zamiarem streszczać jego opowieść, podkreślę tylko, że toczy się ona dynamicznie i płynnie, książkę czyta się zaś z wielkim zainteresowaniem. Uwagę zwrócę więc jedynie na te fragmenty, które mają charakter ściśle porównawczy.

Dla Snydera odmienności obu reżimów są oczywiste. Pisze między innymi, że naziści „[o]drzucali demokrację podobnie jak bolszewicy, czyniąc to jednak w imię wodza, który potrafił najpełniej wyrazić wolę rasy, nie zaś w imię partii, która rozumiała nakazy historii. Porządku światowego w ich ujęciu nie stworzyli (jak uważali bolszewicy) kapitalistyczni imperialiści, lecz spiskujący Żydzi. Problem z nowoczesnym społeczeństwem nie polegał na tym, że akumulacja majątku prowadziła do dominacji jednej z klas; szkopuł tkwił w fakcie, że Żydzi kontrolowali zarówno kapitał finansowy, jak i komunizm [...]” (s. 35). „W 1933 roku rządy sowiecki i nazistowski wydawały się zdolne skutecznie zareagować na ogólnoświatową zapaść gospodarczą. W czasie gdy liberalna demokracja sprawiała wrażenie, że nie potrafi wyciągnąć ludzi z ubóstwa, obydwa ustroje zadziwiały dynamizmem”. „Większość państw europejskich nie miała w perspektywie transformacji społecznej, nie mogła zatem rywalizować z nazistami i Sowietami ani odparować ich argumentów" (s. 38). Masowe zbrodnie wzięły się więc z wielkich utopii transformacji społecznej oraz były odpowiedzią na pewien dramatyczny moment w dziejach - wielki kryzys gospodarczy. Transformacja musiała zacząć się od rolnictwa i rozwiązania kwestii chłopskiej. W wersji stalinowskiej przybrała formę wewnętrznej kolonizacji, której pierwszym etapem stała się powszechna kolektywizacja, a która pociągnęła za sobą miliony ofiar przede wszystkim na Ukrainie. W wersji nazistowskiej nie było innego rozwiązania niż „Drang nach Osten”, kolejna wielka migracja niemieckich rolników na zajmowane przez ich państwo terytoria wschodnie. Spiralę masowych mordów z pewnością zaczęła ekipa Stalina, wywołując w 1932 r. sztuczny głód na Ukrainie, w którego wyniku zmarło kilka milionów chłopów. Na dalsze konsekwencje zaostrzenia represji politycznych nie trzeba było długo czekać, wykorzystując tajemniczą śmierć Siergieja Kirowa w 1934 r., Stalin rozprawił się z rzeczywistą bądź urojoną opozycją kolejno w partii, w aparacie państwowym, w armii, w społeczeństwie (kampania przeciw kułakom), a na koniec w latach 1937-1938 zadecydował o deportacji daleko na Wschód prawie wszystkich mieszkających w europejskiej części ZSRR mniejszości narodowych. Zaczął od mniejszości polskiej z republik białoruskiej i ukraińskiej. W tych latach polityka Hitlera, także konsolidującego w swoich rękach pełnię władzy, może się wydawać jedynie prostym naśladownictwem Stalina i to na małą skalę. Główną prześladowaną grupą stali się Żydzi, od 1933 r. ograniczani w prawach obywatelskich i zmuszani do emigracji, od „nocy kryształowej” z 9/10 listopada 1938 r. brutalnie ograbiani, zabijani i zamykani w obozach koncentracyjnych. 
Zdaniem Snydera - i trudno się z nim nie zgodzić - „terror nazistowski lat 19361938 wyglądał dość podobnie - zamiast karać jednostki za to, co uczyniły, członków grup społecznych zdefiniowanych w kategoriach politycznych karano za to, kim byli” (s. 109). Oprócz Żydów byli to homoseksualiści, włóczędzy, świadkowie Jehowy, osoby fizycznie bądź umysłowo upośledzone.

Wielu podobieństw można się także doszukać w metodach zastosowanych przez oba reżimy przy pacyfikacji zajętej we wrześniu 1939 r. Polski, i Snyder celnie je wskazuje. Obok początkowego terroru i masowych egzekucji członków polskiego establishmentu (akcja A-B, operacja katyńska) oba państwa zdecydowały się na masowe deportacje, przy czym ich możliwości działania ograniczało posiadane terytorium. Niemcy przesiedlali Polaków i Żydów z tzw. ziem wcielonych do Generalnego Gubernatorstwa, Sowieci aktywnych Polaków i żydowskich bieżeńców z centralnej Polski daleko w głąb kraju. Przy wyborze ofiar policje obu reżimów często ze sobą współpracowały, acz jedynie do pewnego stopnia, gdyż wydaje się pewne, że gestapo nie zostało powiadomione o mordzie katyńskim, a NKWD o rozmiarze akcji A-B. Wiele podobieństw wykazuje również - Snyder niestety ten wątek pominął - sposób reorganizacji zajętych polskich terytoriów. Natomiast odmiennie ułożyła się klasyfikacja celów pacyfikacji, u nazistów determinizm ideologiczny wymusił w pierwszej kolejności działania segregacyjne i separacyjne wobec ludności żydowskiej (getta i Judenraty), u Sowietów pragmatyzm kazał skupić się najpierw na Polakach, a w dalszej kolejności na Ukraińcach i Litwinach.

Snyder słusznie podkreśla, że „[w] historii skrwawionych ziem operacja «Barbarossa» wyznacza początek trzeciego okresu [...]. W latach 1941-1945 za niemal wszystkie mordy polityczne odpowiedzialność ponosili Niemcy” (s. 177). Zastanawia się też, w jakiej mierze nowa „polityka zabijania stanowi ukoronowanie nowoczesności” (s. 178). Pozbawieni oświeceniowego optymizmu, „Hitler i Stalin zgadzali się z późnodziewiętnastowieczną darwinowską odmianą tej idei [postępu społecznego]: postęp jest możliwy, ale tylko jako wynik brutalnych zmagań między rasami czy klasami” (ibidem). Dodatkowym warunkiem było dla Niemiec posiadanie samowystarczającego imperium, obojętnego na ogromną przewagę Brytyjczyków na oceanach. Wschód był w rękach sowieckich, Sowietów należało więc z niego na zawsze usunąć. Było to pilne, gdyż jak pisze Snyder, przy nieprzychylnym stosunku Stanów Zjednoczonych i brytyjskiej blokadzie morskiej „Związek Radziecki był jedynym źródłem kalorii dla Niemiec i ich zachodnioeuropejskiego imperium, które - zarówno razem, jak i osobno - musiały importować żywność" (s. 183). W niemieckich planach najważniejsza była Ukraina, której zajęcie pozwoliłoby Niemcom uniezależnić się pod względem aprowizacyjnym. Miał to być teren kolonizacji niemieckiej. By jednak Ukraina, a po części także inne zdobycze terytorialne w ZSRR mogły wyżywić niemiecką Europę, należało radykalnie zmniejszyć popyt konsumpcyjny jej mieszkańców. Najłatwiejszym sposobem wydawała się decymacja ludności, w pierwszej kolejności jeńców sowieckich, miejscowych Żydów i zbędnej ludności miejskiej. Takie były założenia dosyć dobrze znanego Planu Wschodniego, przewidującego śmierć głodową około 30 mln ludzi. Niemcy 
przeliczyły się ze swoimi siłami, nie doceniając równocześnie sił przeciwnika oraz nastrojów panujących w Stanach Zjednoczonych, które jedynie pół roku pozostały neutralne, nawet i w tym okresie pomagając gospodarczo Rosji. Ponadto niemieckie siły pacyfikujące zajęte terytoria były niewystarczające, by w pełni kontrolować zasoby żywnościowe, z czasem okazały się również zbyt słabe, by nie dopuścić do rozwoju ruchu partyzanckiego. Niemniej jednak coraz bardziej rozkręcała się zbrodnicza spirala, wymagająca zagłodzenia milionów jeńców i cywilów, by wykarmić setki tysięcy niemieckich żołnierzy. Snyder pisze, że konsekwencje tego faktu były znacznie głębsze: „brak triumfu w Związku Radzieckim uczynił związek między Wehrmachtem a reżimem nazistowskim nierozerwalnym [...]. Resztki tradycyjnych ideałów żołnierskich trzeba było porzucić na rzecz destrukcyjnej etyki pozwalającej zracjonalizować trudne położenie armii” (s. 201). Ogółem miały zginać nieco ponad 3 mln jeńców sowieckich, w pierwszej jednak kolejności mordowano „politruków, komunistów i Żydów” (s. 207), wyłapanych w obozach przejściowych.

W książce Snydera, dotyczącej dynamiki masowych zbrodni na rozległym terytorium, przeprowadzanych w dość długim okresie, Holokaust bądź inaczej - zgodnie z niemiecką nowomową „ostateczne rozwiązanie kwestii żydowskiej” - rozpoczął się dosyć późno, gdyż dopiero na początku lipca 1941 r. Wcześniejsze etapy prześladowań ludności żydowskiej od 1933 bądź 1939 r. jedynie w niewielkim stopniu wpływały na rozwój wydarzeń wojennych. Hitler nie dlatego rozpoczął wojnę, by wymordować Żydów, choć byli mu oczywiście potrzebni jako uosobienie wroga i od początku myślano o ich usunięciu z terytoriów będących pod kontrolą niemiecką. Zdaniem autora: „sześć miesięcy po rozpoczęciu operacji «Barbarossa» Hitler przeformułował cele wojny w taki sposób, że priorytetem stała się fizyczna eksterminacja Żydów. Jego najbliżsi współpracownicy zdążyli do tego momentu zapoczątkować działania ideologiczne i administracyjne do jej dokonania” (s. 211). To dość radykalna opinia, niewyjaśniająca w żaden sposób, dlaczego nie mogąc wygrać wojny światowej, zrobiono wszystko, by wymordować Żydów europejskich.

Snyder, by uporać się z tym dylematem, zmienia się z chłodnego historyka w psychologa, doszukując się powodów zmiany priorytetów wojennych w rywalizacji najważniejszych współpracowników Hitlera. W jego przekonaniu to „Heydrich i Himmler potrafili czerpać profity z niekorzystnej sytuacji na polu bitwy, modyfikując «ostateczne rozwiązanie» tak, by dało się je przeprowadzić w warunkach wojny przebiegającej niezgodnie z planem” (s. 212). Upraszczając, w takim ujęciu Holokaust staje się zastępczym celem działań wojennych, których tak czy inaczej nie można było zakończyć doraźnym pokojem. Niemniej celem zgodnym ze wstępnymi założeniami przebudowy Europy. Żydzi z jednej strony idealnie nadawali się na kozła ofiarnego, odpowiadającego za niemieckie niepowodzenia, z drugiej zaś zgodnie z nazistowską logiką musieli zająć pierwsze miejsce na drabinie tzw. zbędnych zjadaczy chleba. Opisane założenie potwierdzałaby dynamika mordów na Żydach sowieckich. Podążające za frontem Einsatzgruppen do września mordowały selektywnie żydowskich mężczyzn, uznanych obok komisarzy za podporę reżimu komunistycznego, we wrześniu, a wyraźniej w październiku rozpoczęła się likwi- 
dacja całych skupisk żydowskich. Operacja rozszerzała się ze wschodu na zachód. Od marca 1942 r. przystapiono do likwidacji żydowskich wspólnot w Generalnym Gubernatorstwie i kolejno na tzw. ziemiach włączonych, w Słowacji, Czechach i w dalszej kolejności w Europie Zachodniej i Południowej. Oczywiście, w tym generalnym planie robiono czasowe korekty, do 1943 r. czekano na decyzję o wymordowaniu ważnych dla gospodarki niemieckiej skupisk żydowskich na Śląsku i w Białymstoku, getto łódzkie przetrwało do lata 1944 r.

Mord na ludności żydowskiej miał jeszcze jedną korzyść dla władz niemieckich, mianowicie w krajach wcześniej okupowanych przez Związek Sowiecki bardzo łatwo znajdowano współpracowników w mordowaniu Żydów. Bezpośrednio po wybuchu wojny niemiecko-sowieckiej doszło w całym pasie przyfrontowym do fali lokalnych pogromów, od Litwy i Łotwy po rumuńską Besarabię. W następnych miesiącach tysiące mieszkańców tych terytoriów udało się zwerbować do rozmaitych policji porządkowych, które ściśle współpracowały z SS przy postępującej Zagładzie. Dogodnym pretekstem do tej swoistej mobilizacji była powszechnie podzielana opinia o wyjątkowo znaczącej roli Żydów w sowieckim aparacie przemocy. Szczególnie oni mieli odpowiadać zarówno za dawne, jak i ostatnie zbrodnie NKWD, głównie masowe mordowanie więźniów politycznych w więzieniach, których nie zdążono ewakuować w głąb kraju. Snyder pisze o tym wyraźnie: „Przemoc wobec Żydów służyła zbliżeniu Niemców z częścią lokalnej społeczności nieżydowskiej [...]. Koncepcja, że komunistom służyli jedynie Żydzi, okazała się wygodna nie tylko dla okupantów, ale też dla niektórych okupowanych" (s. 220). Ujawnienie rzeczywistych zbrodni sowieckich ułatwiło „niemieckim esesmanom, policjantom i żołnierzom usprawiedliwić we własnych oczach działania, które wkrótce im nakazano - zabijanie żydowskich kobiet i dzieci” (s. 221). Eskalacja mordów na niespotykaną dotąd skalę wymagała rozmaitych prywatnych racjonalizacji, Snyder cytuje fragment listu austriackiego policjanta dotyczący egzekucji w Mohylewie: „Przy dziesiątym samochodzie już spokojnie celowałem i pewnie strzelałem do tych wielu kobiet, dzieci i niemowląt. Pamiętałem, że w domu czeka na mnie dwójka maluchów, których te hordy potraktowałyby tak samo, jeżeli nie dziesięć razy gorzej” (s. 230). Podobnego zdania był gen. Gustav von Bechtolsheim, dowodzący dywizją w okolicach Mińska - gdyby Sowieci napadli Europę, Żydzi eksterminowaliby Niemców, musieli więc zostać zniszczeni, gdyż „nie byli już ludźmi w europejskim znaczeniu tego słowa” (ibidem).

Po rozpoczęciu jesienią 1941 r. masowych systematycznych mordów ludności żydowskiej na Wschodzie można było już przewidzieć, jak potoczą się jej losy w centrum Europy. Nieznany był jedynie sposób, w jaki Żydzi będą mordowani. Masowych egzekucji nie dałoby się ukryć przed opinią publiczną, wieści o nich zapewne szybko wyciekłyby na Zachód. Masowe strzelanie do niewinnych ludzi działało niekorzystnie na oprawców, policjantów i żołnierzy niemieckich. Poszukiwania rozwiązania tego dylematu nie trwały jednak długo. 9 grudnia 1941 r., a następnie 17 marca 1942 r. ruszyły komory gazowe w Chełmnie nad Nerem (koło Łodzi) i w Bełżcu (Lubelszczyzna). 
Snyder odważnie włącza w swoją narrację jeszcze jeden wątek mający wyjaśnić obsesję Hitlera, by mimo niepowodzeń na froncie wschodnim kontynuować zagładę europejskich Żydów. Pięć dni po japońskim ataku na Pearl Harbor, 12 grudnia 1941 r., Hitler w wąskim gronie najbliższych współpracowników odwołał się do swojego wcześniejszego przemówienia ze stycznia 1939 r., grożąc światowemu żydostwu wytępieniem, jeśli dojdzie do wojny światowej. 12 grudnia 1941 r. stwierdził: „Mamy wojnę światową, zagłada Żydów musi być konieczną konsekwencją” (s. 239). Decyzję przyjęto z zadowoleniem, mówił o tym między innymi Hans Frank na spotkaniu z tzw. rządem GG w Krakowie. Snyder konstatuje: „Żydów obciążano teraz winą za wiszącą w powietrzu katastrofę, której nie wolno było nazwać” (ibidem). Żydzi mieli być zabijani od tej pory jako odpowiedzialni za sojusz brytyjsko-sowiecko-amerykański. W tym mityczno-życzeniowym myśleniu „[a]by uniknąć katastrofy, trzeba było wyeliminować Żydów” (ibidem).

Dziś takie słowa wydają się zwyczajnym absurdem, czy jednak wówczas wypowiedzi osób przekonanych o tajemniczych powiązaniach mającego mieć żydowskie korzenie światowego establishmentu brzmiały równie absurdalnie, nie wszyscy historycy są przekonani.

Alianci mimo kilku spektakularnych gestów - znacząca była tu inicjatywa polskiego rządu emigracyjnego - w praktyce nic dla ratowania europejskich Żydów nie zrobili. Trwali na stanowisku, że jedynym celem wojny jest pokonanie Niemiec nazistowskich, a ukaranie winnych zbrodni ma się dokonać po zwycięstwie. Tak więc Hitler i jego współpracownicy mogli bardzo szybko się zorientować, że Zagłada nie przyniesie żadnych korzyści politycznych, że nie ma szans na separatystyczny pokój czy z Sowietami, czy z zachodnimi Aliantami. W takim ujęciu mord ludności żydowskiej był co najwyżej aktem zemsty, a nie mającym jakiś sens działaniem politycznym. Ciągnąc dalej tę myśl, można założyć, że mordowano nie tylko z powodu wydanego rozkazu, lecz chciano wymordować wszystkich Żydów, ponieważ nienawiść wniknęła bardzo głęboko w niemiecki krwiobieg, a zabijanie niewinnych ludzi przychodziło stosunkowo łatwo i nie wywoływało żadnych wyrzutów sumienia.

Snyder pisze, i nie mogę się z nim do końca zgodzić, iż: „Teraz, gdy destrukcję ZSRR odłożono na czas nieokreślony, polityką czasu wojny stała się kompletna eksterminacja Żydów. Od tej pory pierwszorzędnym zagrożeniem przestały być słowiańskie masy ze swoimi domniemanymi żydowskimi panami, a na pierwszy plan wyszli Żydzi jako tacy” (s. 239). „Od grudnia 1941 r. postanowiono wytępić Żydów jako takich, ponieważ przymierze przeciw Niemcom zyskało na sile. Hitler sięgnął do głębiej skrywanych emocji, by sformułować jeszcze brutalniejsze cele, a świadome swojego trudnego położenia przywództwo niemieckie je zaakceptowało” (s. 240).

Czyżby więc owo „przywództwo niemieckie” tak jak Hitler całkowicie oszalało? Nie mogę uwierzyć, by ci w części dobrze wykształceni i znający zachodni świat generałowie nie zdawali sobie sprawy, że po wojnie odpowiedzą głową za zgodę na niebywały $\mathrm{w}$ dziejach mord. Nic jednak w tej sprawie nie zrobili, nawet spiskow- 
cy związani z Clausem von Stauffenbergiem nie poruszali tego tematu. Jedyne, co przychodzi mi do głowy, to myśl, iż byli oni - i tysiące niższych rangą oficerów oraz nienależących do NSDAP urzędników - przekonani, że szału mordu, jaki opanował nazistów, a także miliony tzw. zwykłych Niemców nie da się powstrzymać, że muszą oni wymordować do końca naród, który przywódcy podsunęli im jako kozła ofiarnego ich całkowitej klęski. Może w ten sposób należy odczytać inną sugestię Snydera: „magia rozumowania w kategoriach rasowych pozwalała przedstawić samo zabijanie Żydów jako niemiecki triumf w chwili, gdy jakiekolwiek inne sukcesy wykraczały poza granice możliwości” (s. 241).

Holokaust miał więc być przede wszystkim odwetem za klęskę - tak Snyder zatytułował jeden z rozdziałów - a nie wytępieniem obcej, wrogiej rasy. Ciągnąc dalej tę myśl, można by dodać, że to ludzie ludziom zgotowali ten los, a nie że ludzie (Niemcy) Żydom zgotowali ten los. Nie jestem co do znaczenia takiego założenia przekonany, mimo że autor w przekonujący sposób udowadnia na przykładzie Białorusi, iż masowe mordowanie tamtejszych Żydów przeprowadzano pod hasłem likwidacji partyzantki sowieckiej. Akcje przeciwko partyzantom niczym nie różniły się od polowania na bezbronnych mieszkańców gett, szukających ratunku w niedostępnych ostępach leśnych. Doświadczeni w pacyfikacjach gett policjanci wyćwiczone metody zastosowali wobec białoruskich chłopów.

Snyder nie zawsze jest w pełni konsekwentny, pisząc o ścisłej zależności między uznaniem Żydów za kozła ofiarnego niepowodzeń wojennych a planem ich zagłady. „Nawet jednak po tym, gdy wyraził [Hitler] swoje życzenie, o momencie ich śmierci decydowały poglądy Niemców na przebieg wojny i związane z nim priorytety gospodarcze. Żydzi umierali częściej, gdy Niemców martwił niedobór żywności, rzadziej zaś, kiedy niepokoił ich brak rąk do pracy” (s. 289). Jego zdaniem, polskich Żydów zaczęto masowo mordować w 1942 r. głównie jako „bezużytecznych zjadaczy chleba” (ibidem), gdy już ograniczono mordowanie jeńców sowieckich, uznanych jednak za zdolnych do pracy przymusowej. A przecież sowieccy, a także polscy, białoruscy i ukraińscy rolnicy nie byli w stanie zastąpić żydowskich rzemieślników i robotników wielkoprzemysłowych ze Śląska. Niemniej jednak przytoczona opinia zgadza się z wiedzą historyczną o przebiegu zagłady polskich Żydów. W przeciwieństwie do Związku Sowieckiego w Gubernatorstwie i na ziemiach włączonych nigdy nie likwidowano od razu całych wspólnot żydowskich, ostatni byli wywożeni uznani za zdolnych do pracy młodzi robotnicy i robotnice, legitymujący się konkretnym zawodem technicznym. Dlaczego jednak w końcu zamordowano i ich? Czy jedynie dlatego, by nie pozostawić świadków największego, bezprecedensowego mordu w dziejach Europy? Czy może jednak z zemsty za przegraną wojnę? Obie odpowiedzi wydają się prawdziwe, chociaż druga bardziej przemawia do wyobraźni. Jak inaczej bowiem wyjaśnić, dlaczego Himmler zdecydował, by doszczętnie zniszczyć pracujące dla Wehrmachtu warszawskie getto, pół roku później na wieść o buntach w Treblince i Sobiborze obozy pracy na Lubelszczyźnie, a w lecie 1944 r. getto łódzkie? Podobnie nie da się inaczej wytłumaczyć nieracjonalnej z powodów militarnych deportacji pół miliona Żydów węgierskich do Auschwitz. 
Zdaniem Snydera, były to ważne dla Himmlera i jego SS symboliczne zwycięstwa. Tak samo miało być w przypadku powstania warszawskiego. „Podobnie jak podczas powstania w getcie warszawskim Himmler ponownie dostrzegł teraz sposobność, by zademonstrować siłę i odnieść symboliczne zwycięstwo" (s. 331). Można się z tą opinią zgodzić, nie wyjaśnia jednak ona, dlaczego nie znalazły się wśród niemieckiego establishmentu, na czele z Wehrmachtem, siły, by tym szaleństwom się przeciwstawić i wynegocjować lepsze warunki kapitulacji. Wiara w Wunderwaffe tego nie tłumaczy, Niemcy wybrali całopalenie, ale czy z przekonania o swoich racjach, wierności wobec Führera i jego wizji, czy może z jakiegoś innego powodu? Nie jest to wcale jasne, jeśli weźmiemy pod uwagę fakt, że spośród tysięcy morderców w nazistowskich mundurach tylko jednostki zdecydowały się na samobójstwo, by nie wpaść w ręce zwycięzców. Część się po prostu poddała w ostatnim momencie, licząc na łaskę, jeszcze więcej próbowało uciec poza Europę. Sądzeni po wojnie, tłumaczyli swoje postępowanie wykonywaniem jedynie rozkazów przełożonych, chyba niezbyt wierząc w swoją niewinność.

Koniec działań wojennych nie przyniósł ludności cywilnej spokoju, był to bowiem czas zemsty. Żołnierze sowieccy zgwałcili większość niemieckich kobiet, które spotkali na swojej drodze, mężczyzn bądź zabijano, bądź brano na przymusowe roboty lub wywożono daleko na Wschód. Stalin zadecydował za zgodą zachodnich aliantów, że państwa Europy Środkowej będą jednolite etniczne, wygnano więc z tych ziem prawie $10 \mathrm{mln}$ Niemców, w tym z Polski 7,6 mln (połowę stanowili uciekinierzy z terenów, do których zbliżała się Armia Czerwona). W polskich i czeskich obozach pracy dla Niemców zapanowały podobne warunki jak w syberyjskich łagrach. Tylko na terytorium Polski pracowało ponad 200 tys. niemieckich jeńców, z czego 30 tys. zmarło w latach 1945-1946. Na dodatek, co mocno podkreślał Władysław Gomułka, „wypędzenie Niemców «związało naród z ustrojem»”. Nie inaczej było w Czechosłowacji i w mniejszym stopniu na Węgrzech i w Rumunii.

Do centralnej i zachodniej Polski przesiedlono Polaków i Żydów z Kresów Wschodnich, ze wschodniej Polski wysiedlono zaś ludność ukraińską, białoruską i litewską. Był to fragment znacznie szerszego zjawiska masowych przesiedleń, które władza stalinowska przeprowadziła w obrębie zachodniej części swojego imperium, okupowanego w latach 1941-1943 przez wojska niemieckie. Wszystkie przesiedlenia miały charakter etniczny, jakby rezygnowano z dawnych zasad walki klasowej przy budowie całkowicie podległego władzy powojennego społeczeństwa.

Stalin zadecydował też, że jedynym zwycięzcą w tzw. wojnie ojczyźnianej będzie naród rosyjski. Jego cierpienia i zasługi musiały przyćmić cierpienia innych narodów, z narodem żydowskim na czele. Upominającego się o pamięć zamordowanych braci Salomona Michoelsa zamordowano, pozorując wypadek samochodowy. Innych członków Żydowskiego Komitetu Antyfaszystowskiego aresztowano bądź zastraszono, informacje o wymiarze Zagłady utajniono, podobnie jak o współpracy kolaborantów różnych narodowości w dziele zabijania. Fakt, że zamordowani Żydzi zaliczeni po wojnie do ofiar narodu sowieckiego, do 1939 bądź 1940 r. 
mieli obywatelstwo polskie, litewskie lub rumuńskie, wzmacniał uzasadnienie, że druga wojna światowa zaczęła się 22 czerwca 1941 r. „Jeżeli stalinowska wizja wojny miała przeważyć, trzeba było zapomnieć o Żydach jako jej najważniejszych ofiarach” (s. 374). Jeszcze bardziej obsesje antysemickie Stalina nabrały znaczenia po powstaniu państwa Izrael, sowieckim Żydom przestano ufać, gdy dostrzeżono ich rosnącą dumę z rozwijającej się nowej ojczyzny, wspartą - co nie było bez znaczenia - przez żydowską diasporę w Stanach Zjednoczonych.

Snyder przyznaje, że stalinowski antysemityzm był obsesją, która mogła doprowadzić do kolejnej fali czystek i morderstw. Społeczeństwo sowieckie lat pięćdziesiątych nie okazało się jednak podatne na kolejną dawkę hipnozy, Stalin nie był już jedynowładcą jak w latach trzydziestych i czterdziestych, jego najbliżsi współpracownicy budowali własne dwory i przygotowywali się do walki o sukcesję. Niemniej jednak ,[s]talinizm odebrał wschodnioeuropejskim Żydom ich historyczny status ofiar Niemców, osadzając ich w zamian w dyskursie imperialistycznego spisku przeciw komunizmowi. [...] Dopóki większą częścią Europy rządzili komuniści, przedstawienie Holocaustu w prawdziwym świetle pozostawało niemożliwe” (s. 406). W odpowiedzi na fałszowanie najnowszej historii przez ideologów sowieckich Zachód zaczął podkreślać cierpienia, „na jakie stalinizm skazał obywateli Związku Radzieckiego. [...] W tej rywalizacji o pamięć Holocaust, inne masowe mordy niemieckie oraz masowe zbrodnie sowieckie stały się trzema odrębnymi historiami, choć w rzeczywistości rozgrywały się w tym samym miejscu i czasie” (s. 407).

Snyder nie poprzestaje na dogłębnym opisie popełnionych zbrodni, słusznie twierdząc, że „[s]ystemy nazistowski i stalinowski trzeba porównać - nie dlatego, aby zrozumieć jeden czy drugi, ale dlatego, aby zrozumieć nasze czasy i nas samych” (s. 410). Słusznie też zauważa, że metody niemieckie i sowieckie równie wiele dzieliło, jak łączyło oraz że do dziś przeważa, głównie na Zachodzie, błędna ocena ich cech kardynalnych. Sowieci raczej koncentrowali więźniów, by pracowali na rzecz gospodarki, równocześnie zabijając znaczą część, by utrzymać strach i posłuszeństwo. Naziści poprzez koncentrację w obozach zamordowali sowieckich jeńców wojennych, bardzo długo nie myśląc w ogóle, by przekształcić ich w siłę roboczą. Żydów długo wykorzystywano gospodarczo w gettach, by swój zamiar unicestwienia narodu-rasy zrealizować w ciężarówkach-komorach gazowych i miejscach zagłady. W uniwersum śmierci drugiej wojny światowej symbol zagłady, jakim jest Auschwitz, w rzeczywistości stanowił wyjątek. „Auschwitz nie był też głównym miejscem eksterminacji dwóch największych społeczności żydowskich w Europie - polskiej i sowieckiej. [...] Auschwitz to końcowe takty fugi śmierci” (s. 413). Jak układa się bilans zabijania przez oba reżimy - naziści $10 \mathrm{mln}$, Sowieci 6 mln. Większość, w tym także 90 procent z 5,4 mln zamordowanych Żydów, pochodziła z badanych przez Snydera „skrwawionych ziem” i tu też została zamordowana. Przywołany przez autora Wasilij Grossman za wspólną cechę obu totalitaryzmów uznał łatwość, z jaką oba ustroje pozbawiały pewne grupy ludzi prawa do człowieczeństwa. 
„Tak więc jako tyrani Hitler i Stalin prowadzili podobną polityką" - jeden chciał w 12 tygodni skolektywizować Związek Sowiecki, drugi mniej więcej w takim samym czasie go podbić - „powodowali katastrofy, winili za nie wskazanych przez siebie wrogów, po czym wykorzystywali śmierć milionów, by dowieść, że ich działania były niezbędne lub pożądane. Każdy z nich miał swoją utopię transformacji, jak również grupę, którą obwiniano, gdy realizacja tej utopii okazywała się niemożliwa, a wreszcie politykę masowych mordów, które dało się ogłosić rodzajem zastępczego zwycięstwa” (s. 418). Zacytowane konkluzje wydają się uzasadnione, liczne podobieństwa między obu ustrojami nie likwidują jednak różnic. Tym, co pozwoliło obu tyranom wprowadzić w życie swoje okrutne marzenia, były nie tyle stworzone bądź rozwinięte przez nich ideologie, ile dobrze zorganizowane partie polityczne, skupiające miliony podobnie myślących ludzi, gotowych z przekonaniem wykonać nawet najbardziej okrutny i bezsensowny rozkaz.

Jaką lekcję wyciągnął świat z kataklizmu drugiej wojny światowej? Snyder w tym wypadku jest ostrożny, przestrzega. „Gdy sensu szukamy w zabijaniu, pojawia się ryzyko, że więcej zabijania przyniesie więcej sensu. Tutaj tkwi być może sens historii - gdzieś pomiędzy odnotowywaniem śmierci a jej nieustającą reinterpretacją. Jedynie historia masowego zabijania może połączyć w jedno liczby ze wspomnieniami. Bez historii wspomnienia stają się prywatne, co oznacza dzisiaj - narodowe, a liczby stają się publiczne, czyli służą za instrument międzynarodowej rywalizacji o tytuł męczenników" (s. 433).

I jeszcze jedno, z czym w pełni trzeba się zgodzić - w latach 1933-1945 oba reżimy zamordowały bądź doprowadziły do śmierci około 14 mln ludzi, my musimy zapamiętać każdą zabitą osobę. 